\title{
Chloroplast transformation in plants: polyethylene glycol (PEG) treatment of protoplasts is an alternative to biolistic delivery systems
}

\author{
Carmel O'Neill ${ }^{\dagger}$, Gábor V. Horváth, Éva Horváth, \\ Philip J. Dix ${ }^{\ddagger}$ and Péter Medgyesy* \\ Biological Research Centre, Hungarian Academy of \\ Sciences, P.O. Box 521, H-6701 Szeged, Hungary
}

\section{Summary}

Nicotiana plumbaginifolia protoplasts were directly transformed by PEG treatment with a cloned $16 \mathrm{~S}$ rRNA gene isolated from a double antibiotic-resistant Nicotiana tabacum plastid mutant. Putative plastid transformants were selected in cell culture by their spectinomycin resistance and identified by their unselected streptomycin resistance. Alternatively, cell lines were selected in the presence of both antibiotics. The cell line (and its regenerated plants) selected solely for spectinomycin resistance demonstrated an extensive segregation of streptomycin resistance in subsequent tests, while the double-selected line showed stable resistance for both antibiotics. The resistance markers were inherited maternally. In the putative plastid transformants the origin of the resistance mutations was identified by the absence of an Aatll site, missing in the donor N. tabacum plastid gene (spectinomycin resistance site) but present in that of wild-type N. plumbaginifolia, and a sequence analysis of the particular nucleotide changes in both resistance sites. Restriction enzyme analysis of total plastid DNA (ptDNA), and the recloning and full sequencing of the fragment introduced, investigated in one of the plastid transformants, showed no DNA rearrangements accompanied with the integration process. Sequence analysis indicated a targeted, homologous integration of the DNA fragment introduced but an unexpectedly complete homology of the parental ptDNA sequences in this region prevented the

Received 8 September 1992; revised 16 November 1992; accepted 27 November 1992.

*For correspondence (fax +3662 433434).

†Present address: Cambridge Laboratory, John Innes Institute, Colney Lane, Norwich, Norfolk, UK.

$\ddagger$ Permanent address: Department of Biology, St. Patrick's College, Maynooth, Co. Kildare, Ireland. location of borders. Although the frequency of plastid transformant colonies $\left(2 \times 1^{-5}\right)$ should still be improved, this method for stable chloroplast DNA transformation is comparable with or more efficient than the particle bombardment techniques.

\section{Introduction}

A substantial amount of data has recently accumulated on the sequence and expression of chloroplast genes in higher plants (Gruissem, 1989; Hiratsuka et al., 1989; Mullet, 1988; Ohyama et al., 1986; Shinozaki et al., 1986a; Sugiura, 1992) providing the essential background to genetic analysis and manipulation of the plastid genome (plastome). This in turn should now build a bridge towards the wealth of information collected from biophysical, biochemical, structural and physiological studies of the plastids. Genetic transformation gives the most useful results when the wild-type information can be stably exchanged with the desired new DNA sequences via homologous recombination. Although plastid DNA recombination is a frequent phenomenon in the green alga Chlamydomonas (Lemieux et al., 1981), higher plants with stably exchanged plastid genes have only been produced through stringent cell selection for genetic complementation after protoplast fusion (Medgyesy et al., 1985a). In distant species combinations, where the entire plastome is non-functional with an alien nucleus, a limited plastid gene transfer by recombination has been able to overcome this incompatibility, offering a genetic tool to identify genes crucial in plastid-nucleus co-operation (Thanh and Medgyesy, 1989). These results have also demonstrated that in higher plants the high number of plastid DNA (ptDNA) copies in a plastid, and plastids in a cell, does not hamper the production of a stable and uniform plastome population of new genetic composition, provided segregation is directed by a suitably stringent selection pressure. Chloroplast gene transfer by recombination, however, seems to be accompanied by numerous, random recombination events scattered along the entire plastome (Fejes et al., 1990; Medgyesy et al., 1985a). In experiments aimed at introducing defined changes, the use of cloned DNA sequences, and a transformation approach, is therefore, unavoidable. It is significant that the apparent barrier to DNA uptake of two membrane 
systems (of the cell and the plastid) has been simultaneously overcome by bombardment with DNA-coated particles from a particle gun, resulting in the homologous replacement of a targeted plastid gene. First demonstrated in Chlamydomonas (Boynton et al., 1988), a wider perspective of application of the method in higher plants soon followed. Plastid-specific chimeric reporter genes have been transiently expressed in plastids of bombarded cultured cells (Daniell et al., 1990; Ye et al., 1990). A selection of cell lines derived from leaf pieces bombarded by a cloned plastid gene coding for antibiotic resistances has led to the production of plants, in which the stably transformed plastome has been inherited in the expected cytoplasmic manner (Sváb et al., 1990). The wide utilization of this breakthrough in chloroplast genetics is presently hampered by the need for constructing or buying a costly apparatus ('Gene Gun'). A widely available means of the delivery of cloned DNA is PEG-mediated direct DNA transformation, which has been successfully employed with yeast spheroplasts (Hinnen et al., 1978) and plant protoplasts (Krens et al., 1982; Negrutiu et al., 1987; Paszkowski et al., 1984) for stable nuclear DNA transformation. Circumstantial evidence has indicated the feasibility of this approach for in vivo plastid DNA transformation as well. Uptake and expression of cloned bacterial and cyanobacterial genes by isolated etioplasts have been demonstrated (Daniell and McFadden, 1987). Data on the plastid location of transiently expressed chimeric reporter genes after Agrobacterium co-cultivation (De Block et al., 1985; Venkateswarlu and Nazar, 1991) and after PEG-mediated DNA uptake (Spörlein et al., 1991), although inconclusive (cf. Cornelissen et al., 1987; Haring and De Block, 1990; Ye et al., 1990), also suggested that plastid DNA can be targeted by cloned DNA through the cytoplasm and the plastid envelope without mechanical action. Here, we report on experiments aimed at stably transforming chloroplast DNA with cloned DNA via a process similar to protoplast fusion-mediated plastid DNA recombination. In our approach the desired cell lines have been selected after a simple PEG-mediated treatment of Nicotiana plumbaginifolia protoplasts with a cloned Nicotiana tabacum plastid gene carrying antibiotic resistance markers.

\section{Results}

Isolation of a plastid gene coding for double antibiotic resistance

A spectinomycin-resistant spontaneous mutant was isolated in callus culture of the streptomycin-resistant N. tabacum SR1 plastid mutant, in the presence of 100 mg $\mathrm{I}^{-1}$ spectinomycin, as a green out-growth on a bleached (sensitive) callus. Seedling tests on the progeny of the regenerated plant demonstrated stable resistance up to $1000 \mathrm{mg} \mathrm{I}^{-1}$ spectinomycin, which was maternally inherited (data not shown). Because of the slower growth of the seedlings in the presence of both antibiotics, double resistance was tested at $500 \mathrm{mg} \mathrm{I}^{-1}$ of each antibiotic (Figure 1). In the SR-SPR3 mutant the appearance of spectinomycin resistance was coupled with the disappearance of an Aatll site in the 16S rRNA gene. The mutation, therefore, resembles other spectinomycin resistance mutations located in a conserved stem structure of the $16 \mathrm{~S}$ rRNA (Fromm et al., 1987; Sváb and Maliga, 1991). Sequence analysis revealed a $C$ to $G$ transversion

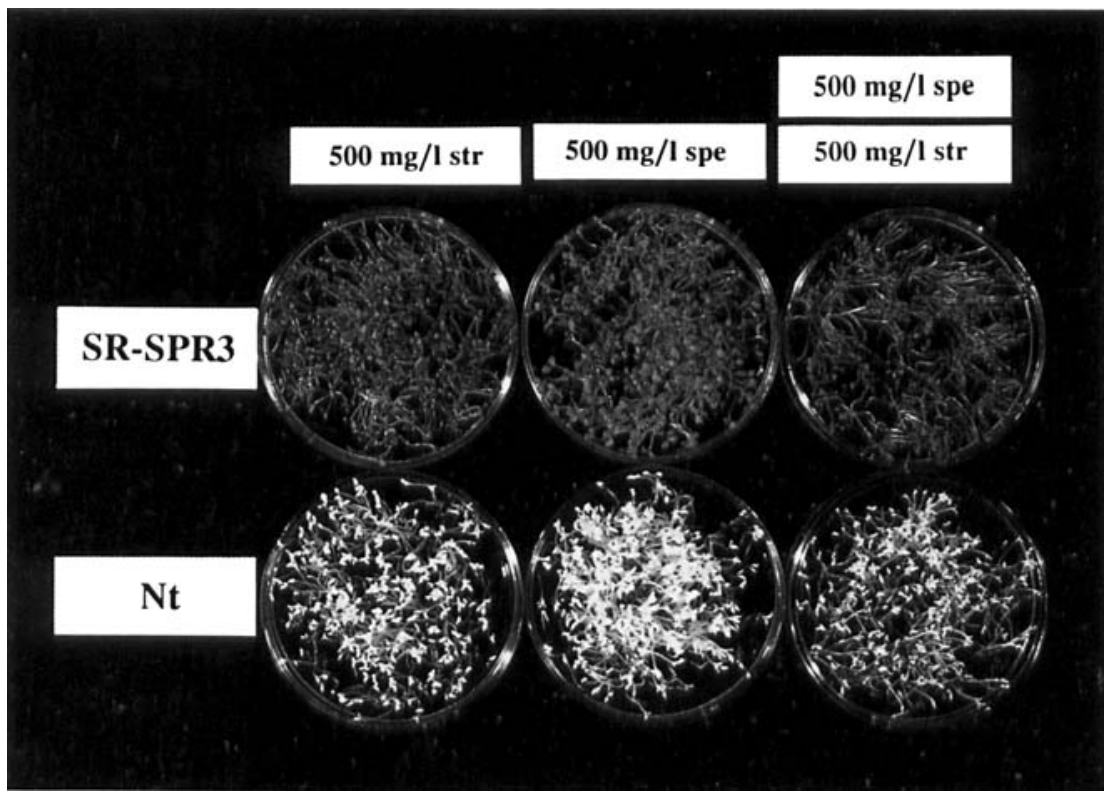

Figure 1. Seedling test for resistance to spectinomycin and/or streptomycin. SR-SPR3, N. tabacum plastid mutant; Nt, wild-type $N$. tabacum. Bleaching indicates sensitivity. 
at position 1138 (cf. Figure 6) in comparison with the wildtype sequence. The 16S rDNA of the SR-SPR3 mutant was cloned as a $3.27 \mathrm{~kb}$ BamHI ptDNA fragment (No. 11) containing the entire gene in N. tabacum (Shinozaki et al., 1986a, 1986b). The cloned gene possessed the streptomycin resistance mutation as a $\mathrm{C}$ to $\mathrm{A}$ transversion at position 860 (Etzold et al., 1987).

\section{Selection and characterization of cell lines with putatively transformed plastids}

DNA uptake conditions leading to a high level of transient expression of a chimeric $\beta$-glucuronidase gene (pIDS411), equivalent to $50 \mathrm{pmol}$ 4-methylumbelliferone (MU) produced per min per $\mu \mathrm{g}$ protein (or per $10^{4}$ protoplasts), were chosen for PEG-mediated transformation. The cloned $16 \mathrm{~S}$ rRNA gene (pTB116) of the SR-SPR3 mutant was introduced into $N$. plumbaginifolia protoplasts using this method (described in Experimental procedures). Cultures were transferred after 8 weeks in liquid culture into solid selective medium containing either $500 \mathrm{mg} \mathrm{I}^{-1}$ spectinomycin or both spectinomycin and streptomycin at 500 $\mathrm{mg} \mathrm{I}^{-1}$ each. In the spectinomycin-containing medium three fast-growing, dark-green colonies appeared against the background of $6.0 \times 10^{4}$ bleached ones in 4 weeks (Figure 2). These colonies were considered as putative plastid transformants and investigated in detail. During this initial culture period no resistant colony appeared in the control culture $\left(2.3 \times 10^{4}\right.$ colonies) derived from protoplasts treated only with pIDS411. An extended culture (over 2 months) resulted in the appearance of five resistant colonies in the control, and five additional ones in the pTB116 treated cultures, which remained resistant after a subculture on selective medium and were considered as spontaneous mutants. All these lines were

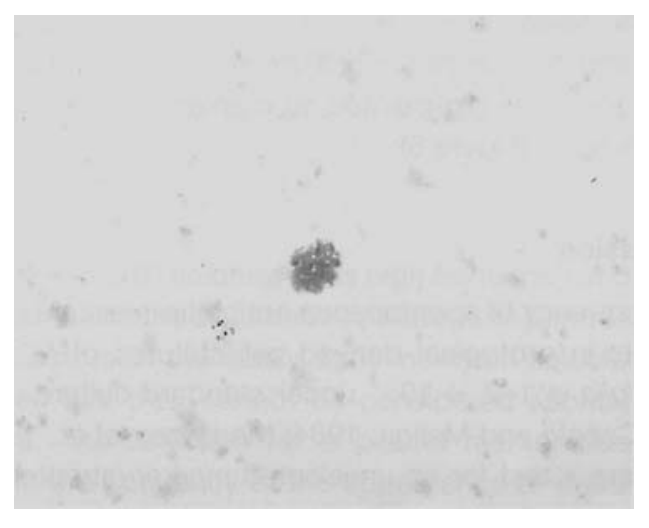

Figure 2. Appearance of a spectinomycin-resistant cell line. In the presence of $500 \mathrm{mg} \mathrm{l}^{-1}$ spectinomycin wild-type $\mathrm{N}$. plumbaginifolia colonies demonstrate a bleaching and a slower growth in comparison with the resistant (green) colony. sensitive to streptomycin in subsequent callus tests. In the spectinomycin/streptomycin-containing medium the colonies grew very slowly, and after 3 months of selective culture a single small, light-green colony could be isolated among $4.9 \times 10^{4}$ bleached colonies.

The three colonies initially selected as spectinomycinresistant were retested on spectinomycin-containing medium and developed into fully resistant calli in 4 weeks. Several pieces from each callus were further tested for their resistance on streptomycin-containing medium. The line No. 1 showed extensive segregation of streptomycin resistance (Figure 3 ) although the majority of the original spectinomycin-resistant callus pieces formed calli also resistant to streptomycin. Lines No. 2 and 3 were completely sensitive. The double-selected colony (line No. 5), and the streptomycin-resistant callus sectors of the line No. 1 tested, formed dark-green but slowly growing callus in the presence of both antibiotics. Plants were regenerated on antibiotic-free medium from shoot primordia of the primary, resistant calli formed in the presence of either spectinomycin (Nos. 1-3) or both antibiotics (No. 5: double-selected line). In the case of line No. 1 shoot primordia were also used from the secondary, resistant calli formed on streptomycin-containing medium. In a leaf test of each of the lines fully resistant leaf calli were formed on spectinomycin-containing medium (10 leaf pieces were tested from different parts of two regenerates in each line). Leaf pieces were also tested for streptomycin resistance. All the shoots derived from only spectinomycin-selected calli showed a full sensitivity (data not shown). A resistant shoot was obtained only from a streptomycin-resistant callus (line No. 1). All the shoots initiated from calli grown in the presence of both antibiotics were fully resistant to streptomycin (line No. 5).

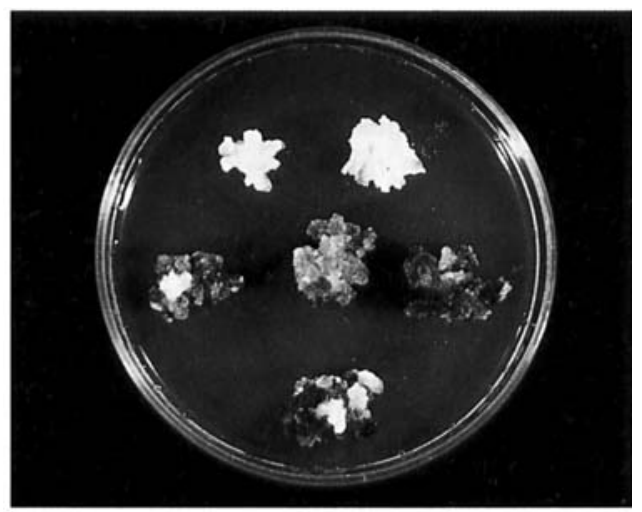

Figure 3. Segregation of streptomycin resistance in callus test. The originally spectinomycin-selected $N$. plumbaginifolia line (No. 1) has derived from transformation with a plastid gene coding for spectinomycin and streptomycin resistances. Formation of white and green sectors in the presence of $500 \mathrm{mg} \mathrm{l}^{-1}$ streptomycin indicates sensitivity and resistance, respectively. 
Seed progenies derived from self-pollinations or crosses with wild-type $N$. plumbaginifolia of the line No. 1 were also tested for spectinomycin and streptomycin resistance (at least 500 seedlings from three seed pods in each cross). The three spectinomycin-selected regenerates tested proved to be homogeneously resistant to spectinomycin, but sensitive to streptomycin. Full streptomycin resistance of the progeny was observed in the case of the streptomycin-resistant regenerate derived from a streptomycin-resistant callus sector of line No. 1. In the case of this particular regenerate the test of more than 3000 seedlings from 15 seed pods demonstrated its homoplasmy for both resistance markers. Resistance to both spectinomycin and streptomycin was inherited maternally (cytoplasmically) in this line (data not shown). Shoots regenerated from the double-selected line (No. 5) grew slowly, were distorted, and were unable to flower.

Identification of the transformed plastomes by sequence analysis

PtDNAs of wild-type N. plumbaginifolia, the N. tabacum SR-SPR3 mutant and a streptomycin-resistant regenerate (line No.1) were analysed with restriction endonucleases which cut inside (Bg/l, Pvull, Smal) or in close proximity (Pvull, Xhol) to the BamHI fragment No.11, or cut in the multi-cloning site of the plasmid (Sall, Smal). No deviation from the expected patterns was detected (data not shown). The isolated $B a m \mathrm{HI}$ fragment No.11 of the line No.1 was identical in length to that of the SR-SPR3 mutant and wild-type N. plumbaginifolia, and was indistinguishable by digestion patterns generated with 37 restriction endonucleases. An Aatll digestion, however, demonstrated the disappearance of the wild-type cutter site in the clones derived from the original mutant and the plastid transformant plant (Figure 4). The other three initially investigated lines, and four spontaneous mutants from the control experiment, were also investigated by cloning and a subsequent Aatll digestion of the appropriate BamHI ptDNA fragment. The results (summarized in Table 1) showed that the lines demonstrating both spectinomycin and streptomycin resistances have simultaneously lost the Aatll marker site. However, this was also the case with two of the six streptomycin-sensitive lines, which necessitated the determination of position and nature of their spectinomycin resistance mutation.

A sequence analysis of the appropriate region of the $16 S$ rRNA genes (cf. Figure 5) elucidated the identity of the mutation to that of the donor ptDNA in those lines (No. 1 and 5) in which streptomycin resistance was also detected. In contrast, in the solely spectinomycin-resistant, spontaneous-mutant, lines a different nucleotide change appeared at a neighbouring position. A further (a)

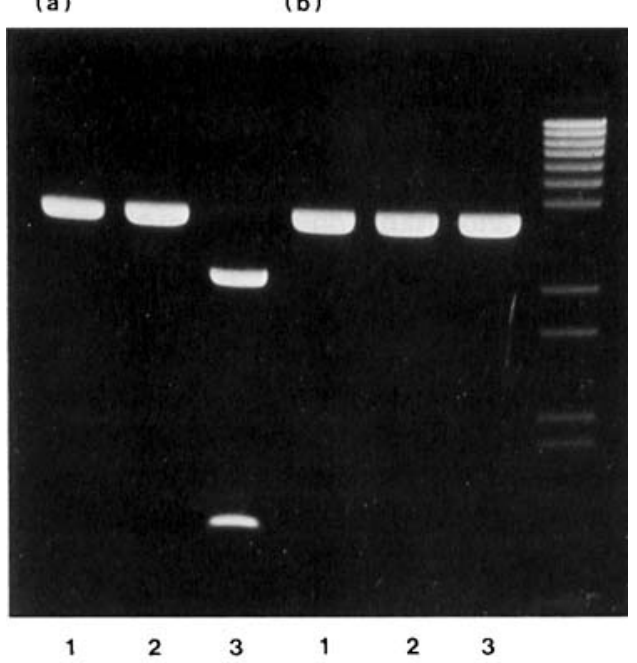

Figure 4. Restriction enzyme analysis for the presence of donor ptDNA. Pattern of Aatll-digested (a) and undigested (b) BamHI ptDNA fragments (No. 11), cloned from the plastid transformant $N$. plumbaginifolia line No. 1 (lane 1), the N. tabacum SR-SPR3 mutant (lane 2) and wild-type N. plumbaginifolia (lane 3). A lambda BstEll digest is also shown (last lane). In N. plumbaginifolia the $3.27 \mathrm{~kb}$ fragment was cut into 2.37 and $0.90 \mathrm{~kb}$ fragments. The loss of this Aatll site in the fragment isolated from the transformed $N$. plumbaginifolia ptDNA indicated the presence of an N. tabacum-specific site.

verification of the plastid transformation in lines No. 1 and 5 was a detection of the expected transition at the same position in a comparison with the donor-type streptomycin resistance mutation (Table 1). The sequences (200-500 bp) determined in these investigations revealed no difference from each other or the corresponding regions of the SR-SPR3 mutant and wild-type N. plumbaginifolia, apart from the resistance mutations described above. For a possible determination of integration borders, the entire $B a m H I$ fragment No.11, isolated from line No.1, was sequenced (Figure 5). A surprisingly complete homology of this ptDNA region in $N$. tabacum SRSPR3 and N. plumbaginifolia allowed only the resistance mutations to be pin-pointed as markers of integration in the line No. 1 (Figure 6).

\section{Discussion}

The frequency of spontaneous antibiotic-resistant plastid mutants in protoplast-derived cell cultures of $N$. plumbaginifolia is $1-2 \times 10^{-4}$ under standard culture conditions (Cséplö and Maliga, 1984; Medgyesy et al., 1985a). Therefore a test for an unselected marker (streptomycin resistance), after the selection for spectinomycin resistance, or an ab ovo selection for double resistance was used to distinguish plastid transformants in our experiments. Both approaches yielded one double-resistant line 
Table 1. Resistance/sensitivity phenotypes and their molecular location for the identification of $N$. plumbaginifolia protoclones with transformed plastomes

\begin{tabular}{|c|c|c|c|c|c|c|}
\hline \multirow[b]{2}{*}{ Lines $^{a}$} & \multirow[b]{2}{*}{ Selection } & \multicolumn{2}{|c|}{ Resistance to } & \multirow{2}{*}{$\begin{array}{l}\text { Presence of } \\
\text { Aatll site }\end{array}$} & \multicolumn{2}{|c|}{ Nucleotide position/change ${ }^{b}$} \\
\hline & & spe & str & & spe $^{r}$ & str $^{r}$ \\
\hline $\mathrm{Np}$ & none & $S$ & $S$ & + & n.a. & n.a. \\
\hline SR-SPR3 & $\operatorname{str}^{r}+\operatorname{spe}^{r}$ & $\mathrm{R}$ & $\mathrm{R}$ & - & $1138 / \mathrm{C} \rightarrow \mathrm{G}$ & $860 / C \rightarrow A$ \\
\hline \multicolumn{7}{|c|}{$\mathrm{Np}+\mathrm{pTB116}$} \\
\hline No. 1 & $\mathrm{spe}^{r}$ & $R$ & $R+S$ & - & $1138 / \mathrm{C} \rightarrow \mathrm{G}$ & $860 / \mathrm{C} \rightarrow \mathrm{A}$ \\
\hline No. 2 & $\mathrm{spe}^{r}$ & $R$ & S & + & n.d. & n.a. \\
\hline No. 3 & $\mathrm{spe}^{r}$ & $\mathrm{R}$ & $S$ & - & $1137 / A \rightarrow G$ & n.a. \\
\hline No. 5 & $(\mathrm{spe} / \mathrm{str})^{r}$ & $\mathrm{R}$ & $\mathrm{R}$ & - & $1138 / \mathrm{C} \rightarrow \mathrm{G}$ & $860 / \mathrm{C} \rightarrow \mathrm{A}$ \\
\hline \multicolumn{7}{|c|}{$N p+p I D S 411$} \\
\hline No. $1^{\prime}$ & $\operatorname{spe}^{r}$ & $R$ & $S$ & + & n.d. & n.a. \\
\hline No. 2' & $\mathrm{spe}^{r}$ & $\mathrm{R}$ & $S$ & - & $1137 / A \rightarrow G$ & n.a. \\
\hline No. $4^{\prime}$ & $\operatorname{spe}^{r}$ & $\mathrm{R}$ & $S$ & + & n.d. & n.a. \\
\hline No. $5^{\prime}$ & $\mathrm{spe}^{r}$ & $\mathrm{R}$ & $S$ & + & n.d. & n.a. \\
\hline
\end{tabular}

${ }^{a} \mathrm{~Np}$, wild-type N. plumbaginifolia; SR-SPR3, N. tabacum plastid mutant resistant to both streptomycin (str) and spectinomycin (spe); pTB116, plasmid carrying the cloned 16S rRNA gene of the SR-SPR3 mutant; pIDS411, plasmid carrying a cloned uidA gene (Stefanov et al., 1991).

${ }^{b}$ Sequence numbering of the 16S rRNA gene has been according to Shinozaki et al. (1986b) with modifications as described in the legend of Figure 6; n.a., not applicable; n.d., not determined.

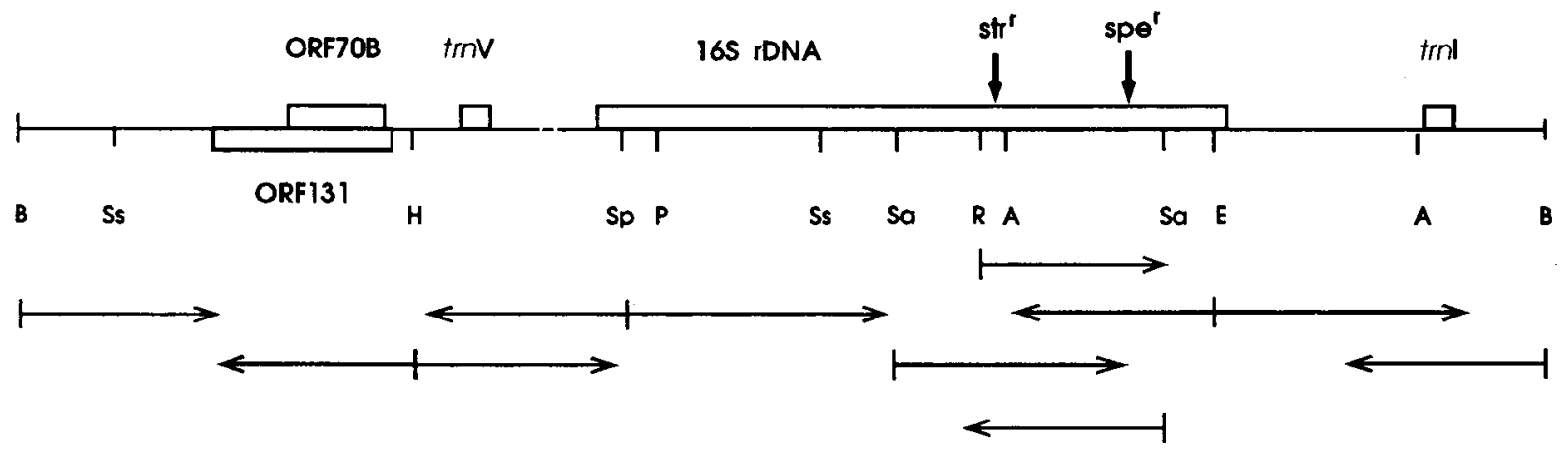

Figure 5. Simplified genetic and molecular map, and the sequencing strategy, of the $3.27 \mathrm{~kb} B a m \mathrm{HI}$ ptDNA fragment No. 11.

The fragment has been cloned from wild-type $N$. plumbaginifolia, the $N$. tabacum SR-SPR3 mutant and a spectinomycin/streptomycin-resistant plastid transformant line (No. 1). The map has been constructed using data of Shinozaki et al. (1986b). The nomenclature of genes follows indications of Hallick and Bottomley (1983). Abbreviations: $16 \mathrm{~S}$ rDNA, 16S rRNA gene; ORF, open reading frame; trnl, tRNA ${ }^{\text {le }}$ gene; trnV, tRNA ${ }^{\mathrm{Val}}$ gene; A, Apal; B, BamHI; E, EcoRl; H, Haell;; P, Pvull; R, Rsal; Sa, Sau3A; Sp, Sphl; Ss, Sstl; str'/sper', antibiotic resistance mutation sites present in the mutant and transformant lines.

among $2-6 \times 10^{4}$ colonies. This high frequency of double resistance, and the abundance of streptomycin-resistant callus sectors in the solely spectinomycin-selected line indicated that they cannot be considered spontaneous mutants. The selection for a plastid marker does not increase the frequency of the appearance of unselected markers resulting from spontaneous mutations after either mutagenic treatment (Csépló and Maliga, 1984), gamma ray irradiation (Csépló et al., 1984) or biolistic transformation (Newman et al., 1990). This is understandable in the light of the existence of numerous DNA copies in a plastid (and numerous plastids in a higher plant cell) which, in the absence of a stringent cell selection during the process of vegetative segregation/copy correction, causes the loss of a newly arisen ptDNA mutation with a high probability (reviewed by Birky, 1983; Birky and Walsh, 1992).

In Chlamydomonas ptDNA the existence of two and six different spectinomycin and streptomycin resistance loci, respectively, has been demonstrated (Harris et al., 1989). Spectinomycin resistance mutations can appear in at least 


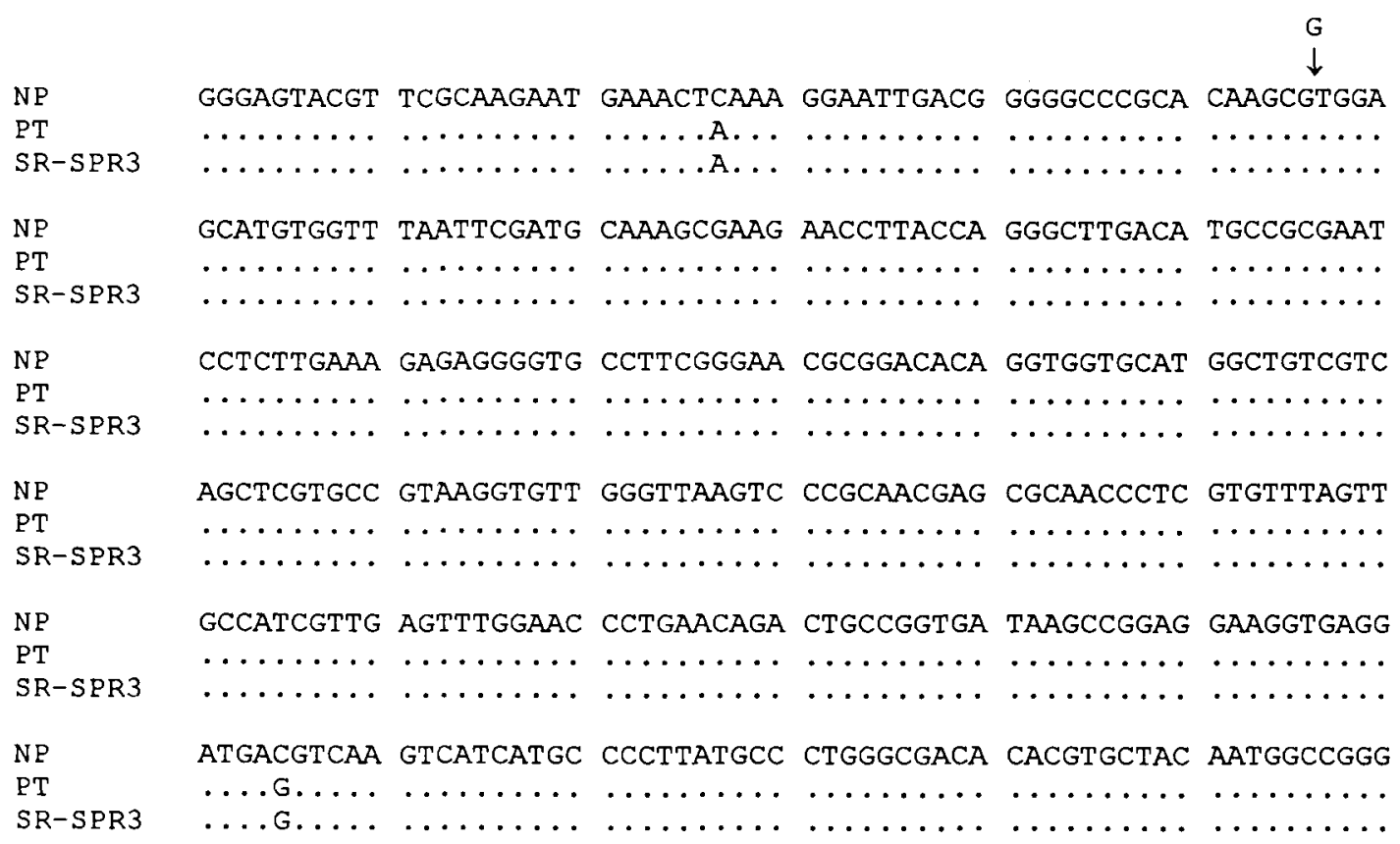

Figure 6. Sequence of a portion of the 16S rDNA conferring the resistance mutation sites applied to plastid DNA transformation.

In addition to the full sequence $\left(5^{\prime}\right.$ to $3^{\prime}$ direction; strand $\left.A\right)$ of wild-type $N$. plumbaginifolia (NP), nucleotide differences are shown detected in the plastid transformant lines No. 1 and 5 (PT) and the donor ptDNA of the N. tabacum plastid mutant (SR-SPR3). An arrow marks the position of an additional nucleotide present in the published $N$. tabacum sequences of the wild-type (Shinozaki et al., 1986b) and the SR1 mutant (Etzold et al., 1987). The remaining parts of the $3.27 \mathrm{~kb} \mathrm{BamHI}$ fragment used for the plastid transformation showed a $100 \%$ homology of the mutant, transformant and wild-type sequences. The 360 bp sequence displayed starts at position 834 in the $16 \mathrm{~S}$ rRNA gene (position 103591 of the entire ptDNA sequence in IRB). The streptomycin resistance mutation is at position 860 , while the spectinomycin resistance mutation is at position 1138 (corresponding to position 1139 in the published $N$. tabacum sequences).

five different nucleotide positions in the 16S rRNA gene in Nicotiana (Fromm et al., 1987; Sváb and Maliga, 1991), three of which impair an Aatll site. Restriction enzyme digestion and nucleotide sequence analysis of the spectinomycin resistance site in six spectinomycin-resistant, spontaneous, mutants and the two double-resistant lines revealed only in the latter case the proper nucleotide change at the expected position, as represented in the donor ptDNA. Plastome-coded streptomycin resistance in Nicotiana can be the result of several mutations in two different genes (Etzold et al., 1987; Fromm et al., 1989; Galili et al., 1989). Therefore, the location of the streptomycin resistance site as the appropriate nucleotide change in the two double-resistant lines further verified that they were bona fide plastid transformants. In these chloroplast transformants the linkage of two genetic and two molecular markers was demonstrated, which were present originally only in the transforming plastid DNA.

Although in our case no statistical analysis is possible, the apparent frequency of plastid transformants among the surviving colonies $\left(2 \times 10^{-5}\right)$ matches well the similarly calculated chloroplast transformation frequencies achieved in Chlamydomonas using the particle gun (Newman et al., 1990). In comparison with the scarce data on the application of the particle gun on whole leaves for plastid transformation in higher plants, the PEGmediated protoplast transformation technique seems to be more efficient. In the latter case a single treatment of protoplasts derived from two leaves resulted in two plastid transformant colonies, while the individual bombardment of more than 300 leaves was necessary to obtain five plastid transformants after leaf disc selection (Staub and Maliga, 1992; Sváb et al., 1990). A similar discrepancy in frequencies exists between the two techniques from the viewpoint of nuclear transformation (compare Negrutiu et al., 1987 with Klein et al., 1988). A plausible explanation of the discrepancy is that, while practically each of the protoplast-derived colonies grow under a selection pressure, in the case of leaf pieces only those cells in the callus-forming parts of the cutting edge, which are exposed to the selective growth conditions, can be recovered as possible transformant cell lines. Furthermore, $80 \%$ of the particles bombarded into the cells end up in the vacuole (Yamashita et al., 1991), and the cell injury from high-velocity microprojectiles (Russel et al., 1992) should also taken into account as a limiting factor of the efficacy of biolistic transformation.

It was notable that in the solely spectinomycin-selected plastid transformant the unselected streptomycin resistance has become gradually eliminated. A similarly exten- 
sive segregation was observed after biolistic plastid transformation in Nicotiana using a similar selection scheme (Sváb et al., 1990). The reason for this phenomenon seems to be the location of both mutations in the same gene, because the same selection scheme resulted in the incorporation of long uninterrupted ptDNA fragments if the resistance mutations were located in two different genes (Staub and Maliga, 1992). In Chlamydomonas the spectinomycin/streptomycin-resistant plastid mutant, carrying both mutations in the $16 \mathrm{~S}$ rDNA, was characterized by a reduced growth and photosynthesis rate if grown under high irradiance (Heifetz et al., 1992). It should also be considered that subtle perturbations in the 16S rRNA higher order structure caused by certain nucleotide substitutions (changing also antibiotic susceptibility) may reduce translational accuracy (Allen and Noller, 1991; Powers and Noller, 1991). Therefore plastids, in which the originally heterogeneous DNA copies lost the unselected marker by intra- and intermolecular recombination/copy correction, might gain a replication advantage during the course of cell multiplication.

Although at the beginning of our experiments the nucleotide sequence of the targeted ptDNA region was published only in N. tabacum, the available data indicated that several nucleotide differences between $N$. tabacum and $N$. plumbaginifolia would aid the location of integration borders after ptDNA transformation. A preliminary sequence analysis of $N$. plumbaginifolia ptDNA in the region of the resistance mutations revealed a missing $G$ at position 890 of the $16 \mathrm{~S}$ rDNA, present in both the original SR1 mutant (Etzold et al., 1987) and the wild-type (Shinozaki et al., 1986b) of $N$. tabacum. Comparative sequence analysis of different ptDNA regions of $N$. tabacum and $N$. plumbaginifolia indicated that at least one nucleotide difference can be expected in a 200-300 bp region (Fejes et al., 1990). Furthermore, a comparison of 165 rDNA sequences of two pea cultivars revealed differences changing the recognition sites of six restriction endonucleases (Cerutti and Jagendorf, 1991), suggesting a possible distinction between the targeted and transforming ptDNA regions in our experiment. In the light of the above data it was surprising that, apart from the resistance mutations, a complete sequence homology was found in the targeted $3.27 \mathrm{~kb}$ region of $N$. plumbaginifolia and the N. tabacum SR-SPR3 mutant. The homology was further verified by sequencing the appropriate ptDNA region of the mutant SR1 (pS272; Medgyesy et al., 1985a) and the authentic wild-type (pTC1; Tohdoh and Sugiura, 1982) clones, indicating that the presence of an additional $G$ in the published sequences was possibly due to a reading error (accordingly, position numbers of spectinomycin resistance loci in Nicotiana should be reduced by one). This homology, which probably highly facilitated the integration process and its accuracy (Fejes et al., 1990;
Newman et al., 1990), prevented determination of the possible borders.

Genetic manipulation of the plastid genome in higher plants either by recombination (Medgyesy et al., 1985a; Thanh and Medgyesy, 1989) or transformation (Staub and Maliga, 1992; Sváb et al., 1990) is in its infancy; in addition to enlargement of the marker pool (Cséplö et al., 1988) it needs an extension and improvement of the available methods to match the efficiency of the well-established nuclear gene transfer techniques. The present paper demonstrates that a simple PEG-mediated DNA uptake by protoplasts is also suitable to generate stable chloroplast DNA transformants. The main significance of this result is that chloroplast transformation in higher plants is now amenable to that kind of cell genetic approach, based on single cell selection, which has proven crucial for the efficient modification of cytoplasmic genomes (reviewed by Medgyesy, 1990). In Chlamydomonas, chloroplast transformation vectors with a selectable antibiotic-resistant plastid gene have proven to be a valuable tool aiding positive selection of targeted gene disruption. The method utilized the frequent co-transformation by defined, impaired photosynthetic genes (not applicable for positive selection) in the antibiotic-resistant plastid transformants, which were then examined under photoautotrophic conditions (Kindle et al., 1991; Newman et al., 1991). In higher plants binding-type antibiotic resistance mutations also fulfil the requirements of such a selection system, because they provide a strong growth advantage to the cell cultures under sufficient selection pressure even in the dark (Cséplö et al., 1993; Malone et al., 1992). This offers the attractive possibility of applying to higher plants studies similar to those carried out with Chlamydomonas. In such a protoplast transformation experiment fast-growing colonies are selected in heterotrophic, antibiotic-containing medium, which can be further tested in a simple photomixotrophic culture (Cséplö and Medgyesy, 1986) for their photosynthetic competence.

\section{Experimental procedures}

\section{In vitro culture conditions}

Nicotiana plumbaginifolia Viviani and N. tabacum L. cV. Petit Havana SR1 (Maliga et al., 1973) were maintained as shoot cultures on RM salts (Murashige and Skoog, 1962) with $2 \%$ sucrose and $0.7 \%$ Bacto-Agar (RM medium) in the light (1500 Ix, $16 \mathrm{~h}$ day, $26^{\circ} \mathrm{C}$ ). Leaf protoplasts were isolated in a solution of $1 \%$ cellulase R10 and $0.3 \%$ macerozyme R10, dissolved in K3 medium (Nagy and Maliga, 1976) containing $0.4 \mathrm{M}$ sucrose as the only osmoticum, as described previously (Menczel et al., 1981). Protoplast yield was about $1 \times 10^{6}$ protoplasts per g leaf. DNAtreated protoplasts were initially cultured in liquid K3 medium, then the colonies were further grown for the selection in solid RMOP medium (Csépló and Maliga, 1984) as described previously (Medgyesy et al., 1985b). Specific features of the colony 
and callus selection are described in the Results section. Plants were regenerated as described earlier (Medgyesy et al., 1985b). Seedlings and leaf calli were tested for their resistance to the appropriate antibiotics as described by Maliga et al. (1982) and Medgyesy et al. (1985a), respectively.

\section{Transforming vectors}

The pIDS411 plasmid is a $5.1 \mathrm{~kb}, \mathrm{pUC}$-based vector containing the Escherichia coli uidA gene, encoding $\beta$-glucuronidase (GUS), supplied with a mannopine synthase (mas) promoter and a nopaline synthase (nos) termination signal (Stefanov et al., 1991). The $6.47 \mathrm{~kb}$ pTB116 vector has been constructed by cloning the $3.27 \mathrm{~kb} B a m \mathrm{HI}$ ptDNA fragment No. 11 containing the entire $16 \mathrm{~S}$ rRNA gene, isolated from the $N$. tabacum SR-SPR3 plastid mutant, into the plasmid Bluescribe M13- (Stratagene) following standard protocols (Sambrook et al., 1989). The pIDS411 and pTB116 plasmids were maintained in E. coli HB101 and XL-1 Blue strains, respectively, and isolated by the alkali lysis/polyethylene glycol precipitation method as described by Sambrook et al. (1989).

\section{Protoplast transformation}

PEG-mediated transformation of protoplasts followed the optimized protocol of Negrutiu et al. (1987) with minor modifications. The transforming buffer (GMg25) contained glucose instead of mannitol. The number of protoplasts in each treatment was $2.5 \times 10^{5}$ in $1 \mathrm{ml}$ of final volume. Fifty micrograms of circular plasmid DNA and no carrier DNA were added. PEG 4000 (Serva; dissolved in GMg25, and heat sterilized) was used at a $20 \%$ final concentration. W5-washed (50 g, $1 \mathrm{~min}$ ) protoplasts were cultured at a density of $5 \times 10^{4}$ protoplasts per ml. Altogether $1 \times$ $10^{6}$ protoplasts were treated with pTB116, and $2.5 \times 10^{5}$ protoplasts were treated with pIDS411. Half of the pTB116-treated cultures were selected in media containing either spectinomycin dihydrochloride (Sigma) or both streptomycin sulphate (Medexport) and spectinomycin, added as filter-sterilized stock solutions. Detection of GUS activity of 1-day-old cultures was performed as described by Jefferson (1987), using a Perkin-Elmer MPF-3 fluorescence spectrophotometer and 4-methylumbelliferyl $\beta$-glucuronide (MUG; Sigma). Soluble protein contents were determined using the Bio-Rad Protein Assay Kit (Bio-Rad Laboratories $\mathrm{GmbH}$ ).

\section{Restriction enzyme analysis and DNA sequencing}

Chioroplasts were isolated from aseptically grown plants in a high ionic strength buffer according to Bookjans et al. (1984). Lysis of chloroplasts and the purification of DNA followed standard protocols (Sambrook et al., 1989). Restriction enzyme digestions were performed according to the instructions of the supplier (Boehringer Mannheim $\mathrm{GmbH}$ ). DNA fragments were separated by horizontal agarose-slab gel electrophoresis, and visualized by ethidium bromide staining following standard protocols (Sambrook et al., 1989). For construction of the transforming vector pTB116, the 3268 bp BamHI fragment No. 11 was isolated from the gel by the optimized freeze-squeeze method (Tautz and Renz, 1983). The same fragment was cloned later on from the different plant lines by shot-gun cloning of BamHI-digested ptDNA into pBS - (Stratagene) using the E. coli strain $\mathrm{DH}^{2} \alpha \mathrm{F}^{\prime}$. Digoxigenin-labelled pTB116 was used as a probe for hybri- dization according to the instructions of the Non-radioactive DNA Labelling and Detection Kit (Boehringer Mannheim GmbH). For physical mapping the particular $\mathrm{BamHI}$ fragments were cut out and isolated from the gel. A 470 bp Rsal-EcoRl fragment, cut from the subcloned, $1277 \mathrm{bp}$ Sphl-EcoRI fragment (cf. Figure 5), was cloned into Smal/ECoRI-digested pBS - for determination of the nucleotide sequence of resistance sites. The sequencing strategy of the whole BamHI fragment is shown on Figure 5. Nucleotide sequences were determined by the dideoxy chain termination method (Sanger et al., 1977) using the Sequenase Version 2.0 DNA Sequencing Kit (United States Biochemical Corporation) with double-stranded DNA templates and M13/pUC direct or reverse primers.

\section{Acknowledgements}

The authors thank Anikó Török and Györgyi Sándor for their excellent technical assistance, Dr István Györi for computer analysis, Dr Csaba Koncz for critical reading of the manuscript, and Béla Dusha for photography. The clones pIDS411, pS272 and pTC1 were generous gifts of Ivan Stefanov, Dr Erzsébet Fejes and Dr Masahiro Sugiura, respectively. The work was supported by OTKA grants (Nos. T5164/92 and 149/91)

\section{References}

Allen, P.N. and Noller, H.F. (1991) A single base substitution in $16 \mathrm{~S}$ ribosomal RNA suppresses streptomycin dependence and increases the frequency of translational errors. Cell, 66, 141-148.

Birky, C.W. (1983) Relaxed cellular controls and organelle heredity. Science, 222, 468-475.

Birky, C.W. and Walsh, J.B. (1992) Biased gene conversion, copy number, and apparent mutation rate differences within chloroplast and bacterial genomes. Genetics, 130, 677-683.

Bookjans, G., Stummann, B.M. and Henningsen, K.W. (1984) Preparation of chloroplast DNA from pea plastids isolated in a medium of high ionic strength. Anal. Biochem. 141, 244-247.

Boynton, J.E., Gillham, N.W., Harris, E.H. et al. (1988) Chloroplast transformation in Chlamydomonas with high velocity microprojectiles. Science, 240, 1534-1538.

Cerutti, H. and Jagendorf, A.T. (1991) Nucleotide sequence of the chloroplast 16S rRNA gene from pea (Pisum sativum L.). Plant Mol. Biol. 17, 125-126.

Cornelissen, M.J., De Block, M., Van Montagu, M., Leemans, J., Schreier, P.H. and Schell, J. (1987) Plastid transformation: a progress report. In Plant DNA Infectious Agents (Hohn, T. and Schell, J., eds). Wien: Springer-Verlag, pp. 311-320.

Cséplö, A. and Maliga, P. (1984) Large scale isolation of maternally inherited lincomycin resistance mutations, in diploid NiCOtiana plumbaginifolia protoplast cultures. Mol. Gen. Genet. 196, 407-412.

Cséplö, A. and Medgyesy, P. (1986) Characteristic symptoms of photosynthesis inhibition by herbicides are expressed in photomixotrophic tissue cultures of Nicotiana. Planta, 168, 24-28.

Cséplö, A., Nagy, F. and Maliga, P. (1984) Interspecific protoplast fusion to rescue a cytoplasmic lincomycin resistance mutation into fertile Nicotiana plumbaginifolia plants. Mol. Gen. Genet. 198, 7-11.

Cséplö, A., Etzold, T., Schell, J. and Schreier, P.H. (1988) Point mutations in the 23S rRNA genes of four lincomycin resistant Nicotiana plumbaginifolia mutants could provide new selec- 
table markers for chloroplast transformation. Mol. Gen. Genet. 214, 295-299.

Cséplö, A., Eigel, L., Horváth, G.V., Medgyesy, P., Herrmann, R.G. and Koop, H.-U. (1993) Subcellular location of lincomycin resistance in Nicotiana mutants. Mol. Gen. Genet. 236, 163-170.

Daniell, H. and McFadden, B.A. (1987) Uptake and expression of bacterial and cyanobacterial genes by isolated cucumber etioplasts. Proc. Natl Acad. Sci. USA, 84, 6349-6353.

Daniell, H., Vivekananda, J., Nielsen, B.L., Ye, G.N., Tewari, K.K. and Sanford, J.C. (1990) Transient foreign gene expression in chloroplasts of cultured tobacco cells after biolistic delivery of chloroplast vectors. Proc. Natl Acad. Sci. USA, 87, $88-92$.

De Block, M., Schell, J. and Van Montagu, M. (1985) Chloroplast transformation by Agrobacterium tumefaciens. EMBO J. 4, 1367-1372.

Etzold, T., Fritz, C.C., Schell, J. and Schreier, P.H. (1987) A point mutation in the chloroplast 16S rRNA gene of a streptomycin resistant Nicotiana tabacum. FEBS Lett. 219, 343-346.

Fejes, E., Engler, D. and Maliga, P. (1990) Extensive homologous chloroplast DNA recombination in the pt14 Nicotiana somatic hybrid. Theor. Appl. Genet. 79, 28-32.

Fromm, H., Edelman, M., Aviv, D. and Galun, E. (1987) The molecular basis for rRNA-dependent spectinomycin resistance in Nicotiana chloroplasts. EMBO J. 6, 3233-3237.

Fromm, H., Galun, E. and Edelman, M. (1989) A novel site for streptomycin resistance in the '530 loop' of chloroplast $16 \mathrm{~S}$ ribosomal RNA. Plant Mol. Biol. 12, 499-505.

Galili, S., Fromm, H., Aviv, D., Edelman, M. and Galun, E. (1989) Ribosomal protein $\mathrm{S} 12$ as a site for streptomycin resistance in Nicotiana chloroplasts. Mol. Gen. Genet. 218, 289-292.

Gruissem, W. (1989) Chloroplast gene expression: how plants turn their plastids on. Cell, 56, 161-170.

Hallick, R.B. and Bottomley, W. (1983) Proposals for the naming of chloroplast genes. Plant Mol. Biol. Rep. 1(4), 38-43.

Haring, M.A. and De Block, M. (1990) New roads towards chloroplast transformation in higher plants. Physiol. Plant. 79, 218-220.

Harris, E.H., Burkhart, B.D., Gillham, N.W. and Boynton, J.E. (1989) Antibiotic resistance mutations in the chloroplast $16 \mathrm{~S}$ and $23 S$ rRNA genes of Chlamydomonas reinhardti: correlation of genetic and physical maps of the chloroplast genome. Genetics, 123, 281-292.

Heifetz, P.B., Lers, A., Boynton, J.E., Gillham, N.W. and Osmond, C.B. (1992) Photosynthetic consequences of specific chloroplast gene mutations affecting synthesis and function of the photosystem II D1 protein. In Research in Photosynthesis, Volume III (Murata, N., ed.). Dordrecht: Kluwer Academic Publishers, pp. 417-420.

Hinnen, A., Hicks, J.B. and Fink, G.R. (1978) Transformation of yeast.Proc. Nat/ Acad. Sci. USA, 75, 1929-1933.

Hiratsuka, J., Shimada, H., Whittier, R., et al. (1989) The complete sequence of the rice (Oryza sativa) chloroplast genome: intermolecular recombination between distinct tRNA genes accounts for a major plastid DNA inversion during the evolution of the cereals. Mol. Gen. Genet. 217, 185-194.

Jefferson, R.A. (1987) Assaying chimeric genes in plants: the GUS gene fusion system. Plant Mol. Biol. Rep. 5, 387-405.

Kindle, K.L., Richards, K.L. and Stern, D.B. (1991) Engineering the chloroplast genome: techniques and capabilities for chloroplast transformation in Chlamydomonas reinhardtii. Proc. Nati Acad. Sci. USA, 88, 1721-1725.

Klein, T.M., Harper, E.C., Sváb, Z., Sanford, J.C., Fromm, M.E. and Maliga, P. (1988) Stable genetic transformation of intact Nicotiana cells by the particle bombardment process. Proc. Natl Acad. Sci. USA, 85, 8502-8505.

Krens, F.A., Molendijk, L., Wullems, G.J. and Schilperoort, R.A. (1982) In vitro transformation of plant protoplasts with Ti-plasmid DNA. Nature, 296, 72-74.

Lemieux, C., Turmel, M. and Lee, R.W. (1981) Physical evidence for recombination of chloroplast DNA in hybrid progeny of Chlamydomonas eugametos and C. moewusii. Curr. Gen. $\mathbf{3}$, 97-103.

Maliga, P., Breznovits, A.S. and Márton, L. (1973) Streptomycin-resistant plants from callus culture of haploid tobacco. Nature, 244, 29-30.

Maliga, P., Lörz, H., Lázár, G. and Nagy, F. (1982) Cytoplastprotoplast fusion for interspecific chloroplast transfer in Nicotiana. Mol. Gen. Genet. 185, 211-215.

Malone, R., Horváth, G.V., Cséplö, A., Búzás, B., Dix, P.J. and Medgyesy, P. (1992) Impact of the stringency of cell selection on plastid segregation in protoplast fusion-derived Nicotiana regenerates. Theor. Appl. Genet. 84, 866-873.

Medgyesy, P. (1990) Selection and analysis of cytoplasmic hybrids. in Plant Cell Line Selection (Dix, P.J., ed.). Weinheim: VCH Publishers, pp. 287-316.

Medgyesy, P., Fejes, E. and Maliga, P. (1985a) Interspecific chloroplast recombination in a Nicotiana somatic hybrid. Proc. Natl Acad. Sci. USA, 82, 6960-6964.

Medgyesy, P., Golling, R. and Nagy, F. (1985b) A light sensitive recipient for the effective transfer of chloroplast and mitochondrial traits by protoplast fusion in Nicotiana. Theor. Appl. Genet. 70, 590-594.

Menczel, L., Nagy, F., Kiss, Z.R. and Maliga, P. (1981) Streptomycin resistant and sensitive somatic hybrids of Nicotiana tabacum + Nicotiana knightiana: correlation of resistance to N. tabacum plastids. Theor. Appl. Genet. 59, 191-195.

Mullet, J.E. (1988) Chloroplast development and gene expression. Ann. Rev. Plant Physiol. Plant Mol. Biol. 39, 475-502.

Murashige, T. and Skoog, F. (1962) A revised medium for rapid growth and bioassays with tobacco tissue cultures. Physiol. Plant. 15, 473-497.

Nagy, J. I. and Maliga, P. (1976) Callus induction and plant regeneration from mesophyll protoplasts of Nicotiana sylvestris. Z. Pflanzenphysiol. 78, 453-455.

Negrutiu, I., Shillito, R., Potrykus, I., Biasini, G. and Sala, F. (1987) Hybrid genes in the analysis of transformation conditions. 1. Setting up a simple method for direct gene transfer in plant protoplasts. Plant Mol. Biol. 8, 363-373.

Newman, S.M., Boynton, J.E., Gillham, N.W., RandolphAnderson, B.L., Johnson, A.M. and Harris, E.H. (1990) Transformation of chloroplast ribosomal RNA genes in Chlamydomonas: molecular and genetic characterization of integration events. Genetics, 126, 875-888.

Newman, S.M., Gillham, N.W., Harris, E.H., Johnson, A.M. and Boynton, J.E. (1991) Targeted disruption of chloroplast genes in Chlamydomonas reinhardtii. Mol. Gen. Genet. 230, 65-74.

Ohyama, K., Fukuzawa, H., Kohchi, T., et al. (1986) Chloroplast gene organization deduced from complete sequence of liverwort Marchantia polymorpha chloroplast DNA. Nature, 322, 572-574.

Paszkowski, J., Shillito, R.D., Saul, M., Mandák, V., Hohn, T., Hohn, B. and Potrykus, I. (1984) Direct gene transfer to plants. EMBO J. 3, 2717-2722.

Powers, T. and Noller, H.F. (1991) A functional pseudoknot in 16 S ribosomal RNA. EMBO J. 10, 2203-2214.

Russell, J.A., Roy, M.K. and Sanford, J.C. (1992) Physical trauma and tungsten toxicity reduce the efficiency of biolistic 
transformation. Plant Physiol. 98, 1050-1056.

Sambrook, J., Fritsch, E.F. and Maniatis, T. (1989) Molecular Cloning: A Laboratory Manual. Cold Spring Harbor, NY: Cold Spring Harbor Laboratory Press.

Sanger, F., Nicklen, S. and Coulson, A.R. (1977) DNA sequencing with chain-terminating inhibitors. Proc. Natl Acad. Sci. USA, 74, 5463-5467.

Shinozaki, K., Ohme, M., Tanaka, M., et al. (1986a) The complete nucleotide sequence of the tobacco chloroplast genome: its gene organization and expression. EMBO J. 5, 2043-2049.

Shinozaki, K., Ohme, M., Tanaka, M., et al. (1986b) The complete nucleotide sequence of the tobacco chloroplast genome. Plant Mol. Biol. Rep. 4, 110-147.

Spörlein, B., Streubel, M., Dahlfeld, G., Westhoff, P. and Koop, H.U. (1991) PEG-mediated plastid transformation: a new system for transient gene expression assays in chloroplasts. Theor. Appl. Genet. 82, 717-722.

Staub, J.M. and Maliga, P. (1992) Long regions of homologous DNA are incorporated into the tobacco plastid genome by transformation. Plant Cell, 4, 39-45.

Stefanov, I., llubaev, S., Fehér, A., Margóczi, K. and Dudits, D. (1991) Promoter and genotype dependent transient expression of a reporter gene in plant protoplasts. Acta Biol. Hung. 42, 323-331.

Sugiura, M. (1992) The chloroplast genome. Plant Mol. Biol. 19, $149-168$.

EMBL Data Library accession number X70938.
Sváb, Z. and Maliga, P. (1991) Mutation proximal to the tRNA binding region of the Nicotiana plastid 16S rRNA confers resistance to spectinomycin. Mol. Gen. Genet. 228, 316-319.

Sváb, Z., Hajdukiewicz, P. and Maliga, P. (1990) Stable transformation of plastids in higher plants. Proc. Natl Acad. Sci. USA, 87, 8526-8530.

Tautz, D. and Renz, M. (1983) An optimized freeze-squeeze method for the recovery of DNA fragments from agarose gels. Anal. Biochem. 132, 14-19.

Thanh, N.D. and Medgyesy, P. (1989) Limited chloroplast gene transfer via recombination overcomes plastome-genome incompatibility between Nicotiana tabacum and Solanum tuberosum. Plant Mol. Biol. 12, 87-93.

Tohdoh, N. and Sugiura, M. (1982) The complete nucleotide sequence of a 165 ribosomal RNA gene from tobacco chloroplasts. Gene, 17, 213-218.

Venkateswarlu, K. and Nazar, R.N. (1991) Evidence for T-DNAmediated gene targeting to tobacco chloroplasts. Bio/Technology, 9, 1103-1105.

Yamashita, T., lida, A. and Morikawa, H. (1991) Evidence that more than $90 \%$ of $\beta$-glucuronidase-expressing cells after particle bombardment directly receive the foreign gene in their nucleus. Plant Physiol. 97, 829-831.

Ye, G.N., Daniell, H. and Sanford, J .C. (1990) Optimization of delivery of foreign DNA into higher-plant chloroplasts.Plant Mol. Biol. 15, 809-819.

\section{Note added in proof}

A parallel publication (Golds et al. (1993) Bio/Technology, 11, 95-97) has also shown the feasibility of PEG-based chloroplast transformation in another Nicotiana species. 